\title{
Entrevista com Nilmário Miranda
}

Cristina Buarque de Hollanda

\section{Nilmário Miranda}

Nilmário Miranda foi preso político da ditadura. Solto em 1976, seguiu seu ativismo por vias legais. Fundou e dirigiu o Jornal dos Bairros, que circulou na periferia de Belo Horizonte. Na transição para a democracia, envolveu-se de perto na criação do Partido dos Trabalhadores em Minas Gerais e nele começou uma longa e fértil estrada nos ambientes da política formal. É um nome incontornável para contar a história institucional dos Direitos Humanos no Brasil. Foi deputado estadual (1987-1991) e federal (1991-1995; 1995-1999; 1999-2003; 2011-2015; 2015-2019) pelo Partidos dos Trabalhadores, (PT), foi Secretário de Direitos Humanos do primeiro governo Lula (2003-2005) e integrante da Comissão de Anistia, do Ministério da Justiça. Jornalista, é também autor de livros que abordam os Direitos Humanos de diferentes perspectivas.

\section{Cristina Buarque de Hollanda}

Professora do Instituto de Estudos Sociais e Políticos da Universidade do Estado do Rio de Janeiro.

E-mail: cristinabuarque@gmail.com

ORCID: https://orcid.org/0000-0002-1600-4044

\section{CRISTINA BUARQUE DE HOLLANDA:}

Nilmário, agradeço imensamente a disponibilidade para me receber para essa conversa. Você poderia retomar, agora com o gravador ligado, sua fala sobre a sua experiência na Fundação Perdeu Abramo?

\section{NILMÁRIO MIRANDA:}

Fui presidente da Fundação Perseu Abramo por quatro anos e fui vice-presidente por seis meses. A Fundação é fantástica, mas eu a acho muito paulista. Sempre critiquei este aspecto. Quando eu fui presidente, o Lula estava encerrando seu mandato e eu viajei para muitos lugares para apresentar o que o governo Lula tinha produzido, e depois fiz o mesmo com o primeiro governo Dilma. Sempre havia um convidado na Fundação (economista, historiador, sociólogo) para comandar o debate e eu buscava me reunir às vésperas com o pessoal dos direitos humanos (os quais já conhecia quase todo mundo) para discutir a importância de dar novos passos: rever a anistia meia-boca do Brasil que anistiou carrascos e algozes, o segundo passo que foi a Comissão de Mortos e Desaparecidos com a qual eu contribuí imensamente (fui membro dela). Depois, a Comissão de Anistia, que foi para todo mundo, que tinha muito foco no vínculo laboral, mas não só. Foi uma novidade. E o quarto passo foi a Comissão Nacional da Verdade; em todos os locais em que me reunia eu anunciava que fatalmente ia surgir a Comissão Nacional da Verdade. Dizia que o governo vinha criando um ambiente favorável a ela 
ENTREVISTA COM NILMÁRIO

MIRANDA

REVISTA ESTUDOS POLÍTICOS Vol. 10 | N.2 ISSN 2177-2851
Cristina Buarque de Hollanda

e dizia que tínhamos de criar nas assembleias locais, nas câmaras de vereadores das capitais onde teve fortes histórias e comissões estaduais. Enquanto o vice-presidente ia cuidar de outras coisas preparatórias para o evento, eu ia me reunir com a grupos da militância de direitos humanos em sedes locais da OAB [Ordem dos Advogados do Brasil] ou em outros lugares. Eu ajudei a criar uma rede de direitos humanos.

\section{CRISTINA BUARQUE DE HOLLANDA:}

Você falou sobre a anistia e eu lembrei de uma passagem do seu livro [Histórias que vivi na história. Geração Editorial, 2018] em que você comenta sobre a euforia em torno do retorno dos exilados, logo em seguida à promulgação da Lei de Anistia. Parecia haver um ambiente de celebração que deixava eventuais críticas à Lei em segundo plano. Quando isso muda? Na sua militância em direitos humanos, quando você acha que aconteceu a inflexão crítica em relação à Lei. Quer dizer, quando ela passou a ser objeto de uma crítica muito dura e aberta da militância?

\section{NILMÁRIO MIRANDA:}

Para falar dessa questão da anistia vou recuar um pouco no tempo. Eu voltei para viver a vida comum em 75. Em 76, voltei para a Universidade em Minas Gerais (UFMG), onde eu havia participado intensamente das atividades antes da clandestinidade, das prisões. $O$ que unificava todo mundo era a anistia. Havia surgido o Movimento Feminino pela Anistia, aqui [em Minas Gerais] tinha a Dona Helena Greco e muitas famílias importantes [na resistência à ditadura]: Pezzuti, família da Ana Leite, família Lins. Famílias que tinham parentes mortos, no exílio ou na clandestinidade. $\mathrm{O}$ tema da tortura ainda era muito presente e havia muitos grupos à volta deste tema, mas com muita disputa interna. A esquerda que enfrentou a ditadura estava quase toda destruída. Tinha os remanescentes ou dissidências que perduraram, mas conseguimos que todos se unissem pela democracia e pela anistia. Eu não tinha formação democrática. Nenhum de nós tinha. A gente tinha até uma resistência porque associava a democracia ao controle do Congresso, oligarquias, como sempre foi de fato. A democracia é muito frágil e retórica. Mas de 76 nós entramos a fundo nesta causa e quando digo nós, digo o Brasil inteiro, milhares de pessoas. Defendíamos a democracia como o regime que permitia o conflito, a liberdade de pensamento, de ideologias, dos credos. E conflito não só de classe, mas também étnico e de gênero, o que fomos descobrindo depois. Então houve um movimento democrático. Na cadeia, eu mudei a minha forma de ver a democracia e quando eu saí já havia alguma formação democrática. Tinha uma tendência até mesmo dos colegas exilados, que tinham vivido na Europa, alguns tinham vivido a experiência do Allende. Democracia e anistia tornaram-se uma pauta comum, independentemente da corrente: stalinista, trotskista, democrata-cristão.

\section{CRISTINA BUARQUE DE HOLLANDA:}

A anistia passou a significar o caminho de retorno à democracia.

\section{NILMÁRIO MIRANDA:}

O movimento pela anistia tornou-se um movimento social, e não só um movimento político. Eu me lembro um dia em que a Elis Regina veio ao Palácio das Artes, 1200 lugares lotados, e quando ela cantou $O$ bêbado e a equilibrista todos ficaram de pé. Era um hino. A anistia entrou forte no povo inclusive na classe operária. Nós vimos lideranças operárias que foram vítimas da 
ENTREVISTA COM NILMÁRIO

MIRANDA

REVISTA ESTUDOS POLÍTICOS Vol. 10 | N.2 ISSN 2177-2851
Cristina Buarque de Hollanda

ditadura e que tiveram de largar suas profissões, suas cidades, suas famílias e tiveram de sofrer na pele. Isso gerou praticamente um movimento social. Na época não se usava muito pesquisa de opinião, mas se tivesse daria como resultado a maioria da população favorável à anistia. Estava o Brizola, o Arraes, o Prestes. Acho que havia uma maioria para a anistia ampla, geral e irrestrita. A anistia foi uma frustração, porque foi [derrotada por] muito pouco voto e tinha produzido um herói que saiu do lado de lá [da Arena]. Um usineiro, o Teotônio Vilela, maior caso de conversão política da história moderna! Foi uma frustração muito grande. Tinha havido o pacote de Abril de 77, que mostrou que, independentemente do número de votos, [a Arena] seria sempre a minoria. E uma das razões [para isso] era a anistia: não criar uma maioria que pudesse votar a anistia ampla, geral e irrestrita. De 74 para 78 [era] óbvio que o MDB [Movimento Democrático Brasileiro] ia crescer mais e teria maioria em muitos estados: Rio, Pernambuco, Ceará, Paraná, Rio Grande do Sul. Era quase natural que houvesse. Cada assembleia também elegeria o governador que quisesse. Teve assembleia que elegeu o governador indicado pela ditadura, mas ia dar voz para elegerem quem quisesse, o que já ia esvaziar a ditadura. E, se o MDB elegesse maioria no Congresso, não elegeria o general tirado dos quartéis, que eram o verdadeiro escrutínio.

\section{CRISTINA BUARQUE DE HOLLANDA:}

Esvaziaria a ditadura por dentro.

\section{NILMÁRIO MIRANDA:}

E o próprio voto indireto ia eleger alguém que não fosse militar. Para evitar isso, o Pacote de Abril foi fundamental e assegurou o formato da lei de anistia que eles queriam. Até as eleições de 80, o Pacote de Abril permaneceu no sistema político. A Constituinte [de 1988] não conseguiu mudar a natureza do sistema político gerado pelo Pacote de Abril. Com a figura do senador biônico eles transformaram os territórios em estados para poder ter o controle e a maioria do Congresso, mesmo sem voto. A anistia ampla, geral e irrestrita perdeu por oito votos. Era uma profunda decepção porque, para nós, perdoar a tortura era um tapa na cara. Nós percebíamos a posição de um país diante da tortura como o cerne de um processo civilizatório, que define o grau de avanço civilizatório de um país. Eu fui várias vezes ao Rio de Janeiro com minha mulher [Stael Luíza Rocha de Santana] receber amigos [que voltavam do exílio]. O tio dela, Guido Rocha, que era uma lenda. Era uma festa quando os exilados retornavam.

\section{CRISTINA BUARQUE DE HOLLANDA:}

Era o reencontro das famílias e dos amigos.

\section{NILMÁRIO MIRANDA:}

Todos iam recebê-los. Então tinha essa dupla face. E sabíamos que com o retorno das lideranças anteriores a 64 que saíram com o AI-5 [Ato Institucional $n^{\circ} 5$ ] implodia o controle político da ditadura. Sabíamos que era estratégico ter a anistia para recompor as forças democráticas contra a ditadura. Essa duplicidade sempre esteve presente. A anistia não foi um pacto. Eu fiz uma diferença entre pacto e conciliação no meu livro. 88 é um pacto celebrado entre os debaixo e os de cima, entre direita, esquerda e centro, entre movimentos sociais emergentes e intelectualidade. Ali está um pacto. Já a anistia foi conciliação, ou seja, prevalece 
ENTREVISTA COM NILMÁRIO

MIRANDA

REVISTA ESTUDOS POLÍTICOS Vol. 10 | N.2 ISSN 2177-2851
Cristina Buarque de Hollanda

aquele grupo que vai passando de geração em geração e que é capaz de promover conciliação - 1824, 1842, 1888, 1891, a saída do Estado Novo, a eleição indireta. A reconciliação prevalece, com a anistia, inclusive. E pacto foi em 88.

\section{CRISTINA BUARQUE DE HOLLANDA:}

Então, para você, 1988 teve o sentido de uma refundação?

\section{NILMÁRIO MIRANDA:}

Por uma relação de desequilíbrio de força, os de baixo não conseguem por na Constituição de 88 tudo pelo que sonham. Mas era uma visão democrática. No meu caso em particular, eu, que já estava muito engajado com os direitos humanos... os trinta artigos da Declaração Universal estão na Constituição. Isso é fundamental. O que diz respeito ao mundo do trabalho - ao povo - quase tudo dependia da regulamentação em lei, o que era outra dificuldade. $O$ que era auto aplicado era para o capital. Tudo que era favorecer o trabalhador no mundo do trabalho exigia regulamentação no cenário da conciliação, que é o Congresso. Tipificar a tortura para uma pequena parte de nós era fundamental e foi só em 97, dez anos depois da Constituição, que conseguimos aprovar. E mesmo assim tivemos de engolir que a babá que batia na criança fosse enquadrada neste crime quando, para nós, a tortura era o crime de Estado. Não é um crime de um único indivíduo, este é outro tipo penal. Assim como a Lei de Anistia perdoou as vítimas do Estado e perdoou os algozes, a tortura também entrava como ato civil, o que descaracterizava um pouco a concepção de tortura que, mundialmente é reconhecida como um crime de Estado.

A correlação de forças que permite a aprovação da lei 9.145, [que incluiu entre outros] o grupo Tortura Nunca Mais do Rio, era radicalmente contrário [a tal entendimento], porque achava que a vítima não devia provar a responsabilidade objetiva do Estado, mas que tinha que derrubar a anistia. Mas e a força para fazê-lo? E havia o dilema constante para nós de fazer o que a correlação de forças tornava possível e não o que queríamos. Todas as conquistas vêm com essa marca. A anistia estabeleceu que o militar era intocável.

\section{CRISTINA BUARQUE DE HOLLANDA:}

Nilmário, quando você se elegeu deputado, logo no primeiro mandato, tentou desarquivar uma CPI sobre mortos e desaparecidos que já tinha sido cogitada na legislatura anterior. Você conhece a história deste arquivamento?

\section{NILMÁRIO MIRANDA:}

A CPI precisa de 171 deputados. Eu não estava na Câmara e o Plínio de Arruda Sampaio da bancada do PT renunciou para ser candidato a governador em São Paulo e assumiu o seu suplente, [Luiz Eduardo] Greenhalgh, que foi presidente do CBA [Comitê Brasileiro de Anistia]. Estava lá o Sigmaringa Seixas, que era um ex-advogado de Brasília e que trabalhava no STM [Supremo Tribunal Militar], na segunda instância, nos processos contra os presos políticos. Sigmaringa e Greenhalgh, nos anos noventa, conseguiram 171 assinaturas, mas a CPI não foi instaurada. Quando muda a legislatura aquela CPI foi automaticamente arquivada.

\section{CRISTINA BUARQUE DE HOLLANDA:}

Não é surpreendente que tenham conseguido tantas assinaturas num contexto em que ainda pairava um certo medo do retorno autoritário? 
ENTREVISTA COM NILMÁRIO

MIRANDA

REVISTA ESTUDOS POLÍTICOS Vol. 10 | N.2 ISSN 2177-2851
Cristina Buarque de Hollanda

\section{NILMÁRIO MIRANDA:}

Eles conseguiram as assinaturas porque foram batalhando. O Brasil estava muito voltado para as eleições, para os senadores e deputados. O Congresso ficou esvaziado e alguns deputados passaram a se encontrar a cada quinze dias e assim eles conseguiram o milagre das 171 assinaturas. Quando eu tomei posse eu pedi o desarquivamento da CPI para que ela retornasse à ordem do dia, surgiu aquela conversa fantástica me dizendo: "olha, não mexe nisso, não!" Eu escutava coisas do tipo: a CPI instaurada vai ter poder e você vai cutucar a onça com a vara curta e vem toda aquela conversa. Nós éramos um grupo pequeno; o PT [Partido dos Trabalhadores] tinha 35 deputados, tínhamos crescido muito.

\section{CRISTINA BUARQUE DE HOLLANDA:}

Dentro do PT, o apoio para a agenda dos mortos e desaparecidos era irrestrito?

\section{NILMÁRIO MIRANDA:}

Mais ou menos. Não é que fossem contra, mas achavam que não era prioridade e achavam perigoso, que íamos esbarrar aonde esbarrou. A esquerda era pequena ainda e o PT tinha muitas dúvidas sobre a Constituição. Não que ela não tenha sido um avanço, mas não sabíamos no que ia dar as incompletudes e limites dela. Na segurança pública manteve-se muita coisa da ditadura, como as polícias militares, por exemplo, que se organizavam como se fossem Forças Armadas. A reforma tributária não mexeu no sistema político de abril de 77, manteve alguns de seus fundamentos. Não avançou no controle do tamanho da propriedade. Nunca conseguiu transformar o que estava na Constituição, positivar o direito e trazer para a lei no caso do controle da mídia por poucas famílias. Direito à comunicação, à reforma urbana, que ficou só no papel e não conseguimos trazer a função social da propriedade urbana para impedir essa explosão dessas metrópoles no Brasil. O que virou a vida nas grandes cidades, não conseguimos alterar isso nem pela Constituição nem pela lei. Até na minha área, antes de eu pegar direitos humanos o meu tema era a reforma urbana.

\section{CRISTINA BUARQUE DE HOLLANDA:}

Mas quando você acha que setores da esquerda começaram a perder o medo e vocalizar a demanda pela revisão da lei da anistia ou, ao menos, da interpretação corrente sobre ela?

\section{NILMÁRIO MIRANDA:}

O PT era muito pequeno. Tinha 35 deputados em 90. Em 94 deu um salto e foi para 51. Deu outro salto em 98 e foi para 65, de 513 deputados. Não tinha quase nada no Senado. O PC do B [Partido Comunista do Brasil] sempre foi um partido importantíssimo, mas pequeno. O PDT [Partido Democrático Trabalhista], quando o Brizola estava lá, manteve-se à esquerda, mas depois dele perdeu essa tendência geral e passou a ter feições muito distintas em cada estado brasileiro. O PSB [Partido Socialista do Brasil] era um partido de centro-esquerda, muitas vezes mais para a direita do que para a esquerda. Era pequeno também. Todo mundo junto. O dilema do Lula quando ganhou [a eleição para presidente] foi esse. Numa eleição em 2002, juntando todo o mundo que o apoiou, chegava a 140 de 513 deputados. Teve que fazer alianças heterodoxas para ultrapassar 257 necessários para um impeachment, que é a única maneira de tirar um presidente. Eu chamo a década de 90 de década de ouro porque foi a positivação do 
ENTREVISTA COM NILMÁRIO

MIRANDA

REVISTA ESTUDOS POLÍTICOS Vol. 10 | N.2 ISSN 2177-2851
Cristina Buarque de Hollanda

direito, com as leis ordinárias. A qualidade destas leis também foi importante porque elas tiravam não o máximo, mas o mínimo que a Constituição permitia. E a PEC de 2000 em diante era Constituição, leis e política pública, para chegar à vida das pessoas, que era uma coisa distante. Não mexia com a vida real das dezenas de milhões de excluídos de direitos. E se houvesse uma volta da ditadura militar?

\section{CRISTINA BUARQUE DE HOLLANDA:}

Esse medo existia ainda em 2000?

\section{NILMÁRIO MIRANDA:}

Sempre esteve presente. Teoricamente ninguém queria lidar com revogar a anistia, com o julgamento dos torturadores.

\section{CRISTINA BUARQUE DE HOLLANDA:}

Imagino que fosse uma demanda mais articulada por familiares [de mortos e desaparecidos políticos] do que por partidos políticos?

\section{NILMÁRIO MIRANDA:}

E os direitos humanos ganharam uma força com os tratados internacionais, também o rumo que a Argentina tomou, o Chile e o próprio Paraguai. Eles julgaram os torturadores. Eu tinha um laço muito e um trânsito muito forte com esses países todos, nossa articulação no continente era forte em relação a isso. Mas com o povão, não. $E$ também dentro do país a mídia trabalhou fortemente a ideia de que direitos humanos era para defender bandidos. Sempre estigmatizou os direitos humanos. A gente falava contra a tortura e as pessoas entendiam que era uma fala contra o policial para deixar os bandidos soltos. Essa narrativa ficou muito forte no Brasil e isolou a gente do povo.

Quando votamos contra a tortura, a tipificação foi em 97, eu fui relator da Comissão de Direitos Humanos e o Almino Afonso foi relator pela Comissão de Constituição e Justiça, que era o coração do parlamento. Eu lembro que o Bolsonaro disse no parlamento que a ditadura só foi boba de nos ter deixado vivos. O Agnaldo Timóteo é um cara que adora o Lula, mas ele tomou a palavra e disse que nós pretendíamos acabar com a polícia no Brasil! Ou seja, tirando a tortura acaba a polícia! Ou seja, vinculavam a tortura à própria existência da polícia. Essa tensão sempre esteve presente. E o rádio e a televisão com aqueles programas hiperpopulares policiais, eram contra os direitos humanos. Mas nós avançamos muito. Na Perseu Abramo, nós fazíamos pesquisas de percepções do povo, não pesquisas eleitorais porque a natureza da instituição nem permite. Avaliávamos temas como racismo, feminismo, tortura, pena de morte, pauta LGBT. Em 2007, 2008 e 2009 víamos que formava uma pequena maioria contra tortura, contra pena de morte (um tema que sempre teve posição popular majoritariamente a favor), do feminismo, da mulher, do racismo, do próprio LGBT, que era a fronteira das fronteiras da percepção de um avanço civilizatório. Em 2010 já havia uma ligeira maioria a favor da pauta LGBT. Uma mudança de percepções. É um processo muito difícil. Os governos Lula e Dilma tinham essa dificuldade. Não quiseram apoiar quando o Jornal do Brasil quebrou; o José Dirceu propôs apoiar que fosse incentivado uma nova construção do Jornal do Brasil, o que não teve simpatia dentro do governo. Argumentavam que quando Vargas fundou o jornal $A$ última hora 
ele caiu. Mais difícil que a reforma agrária é a reforma do ar, disputa de opinião. Ela acirra o conflito. Quando quebrou a manchete do mensalão, aí de novo teve gente que sugeriu novamente o surgimento de pelo menos uma televisão progressista, UM jornal progressista. Mas a maioria dizia que ia acirrar. Então, não havia isso. Então o plano de ação em direitos humanos era de se aproximar do MEC [Ministério da Educação] e do Ministério da Cultura para a gente trabalhar a cultura. Não basta dar direito aos jovens, quem fazia a cabeça do jovem que teve direito à escola técnica foram os fundamentalistas. A teoria da meritocracia foi inculcada na cabeça destes jovens - cujo lema é "não foi a política pública que abriu caminhos para você conseguir chegar até aqui. Foi você, com a sua inteligência", como se seus tios e pais fossem todos burros e só por isso não chegaram até aqui. Era um discurso que desvinculava da política pública, eu sempre falei isso. Não basta abrir a porta do alcance ao direito via política pública, é preciso haver também mudanças culturais, e esse foi o ponto fraco do nosso governo. Hoje Lula e Dilma reconhecem isso, que sempre foi um dilema pela correlação de forças. Éramos obrigados a nos aliar também com o pessoal da Universal [Igreja Universal do Reino de Deus], esses lunáticos que estão no poder agora. Houve um tempo em que eram nossos aliados. A gente atingia o povão com o direito à alimentação, direito à vida, e os tínhamos como aliados. Agora eles se tornaram inimigos das nossas políticas! E como aliados, se a gente se entrasse no campo dos mortos e desaparecidos, da tortura, da desmilitarização da polícia, íamos perder aliados e ia ficar ingovernável.

\section{CRISTINA BUARQUE DE HOLLANDA:}

Foi uma agenda muito difícil de avançar.

\section{NILMÁRIO MIRANDA:}

Sempre. Nunca venceu a maioria, não por questões doutrinárias, mas sempre teve essa dificuldade.

\section{CRISTINA BUARQUE DE HOLLANDA:}

Você pode contar sobre as rotinas de funcionamento da Comissão Externa [sobre Mortos e Desaparecidos Políticos] e da Comissão Especial de Mortos e Desaparecidos? O que foi possível fazer? Os mandatos foram mandatos bastante restritos, sobretudo o da primeira comissão.

\section{NILMÁRIO MIRANDA:}

A Comissão Externa não tinha poderes, era um poder simbólico. Não podia requisitar nem convocar documentos. E não era do interesse da maioria dos partidos. Do PMDB [Partido do Movimento Democrático Brasileiro] participava um deputado, que era o Alberto Valadão, cujo irmão Arildo era desaparecido no Araguaia. Ele era um deputado respeitado. Não era representante DO PMDB nesse assunto. Do PV [Partido Verde] havia um ex-preso político.

\section{CRISTINA BUARQUE DE HOLLANDA:}

Imagino que a condição comum de atingidos pela violência da ditadura tenha construído laços que ultrapassaram as fidelidades partidárias.

\section{NILMÁRIO MIRANDA:}

Quem tocava a comissão era eu, Sigmaringa Seixas... 
ENTREVISTA COM NILMÁRIO

MIRANDA

REVISTA ESTUDOS POLÍTICOS Vol. 10 | N.2 ISSN 2177-2851
Cristina Buarque de Hollanda

\section{CRISTINA BUARQUE DE HOLLANDA:}

Que tinha sido o propositor da CPI de Mortos e Desaparecidos na legislatura anterior.

\section{NILMÁRIO MIRANDA:}

E que também foi advogado de preso político durante o período da ditadura. Ele e o pai dele. No PC do B, havia o Aldo Arantes e o Haroldo Lima, dois ex-presos, que sobreviveram ao massacre da Lapa. Sempre alguém do PSB, mas ia sempre com muita insistência.

\section{CRISTINA BUARQUE DE HOLLANDA:}

Mas no PSB não tinha quem tivesse sido atingido pela ditadura de maneira mais direta?

\section{NILMÁRIO MIRANDA:}

Tinha o deputado Roberto Franca. Esse era ativo conosco, porque em Pernambuco a repressão foi barra pesadíssima - repressão ao Miguel Arraes, ao Dom Hélder, à Igreja. Pegou muita gente. Muitos mortos e desaparecidos, asilados, exilados, presos políticos. Teve Itamaracá e aquele presídio virou uma tradição de luta. Anteontem eu falei com Amparo Araújo e ele me disse que a Corte Interamericana de Direitos Humanos fez a admissibilidade do caso do companheiro dele José da Cunha, dez anos depois que ele ingressou com o pedido na OEA [Organização dos Estados Americanos]. Vários recorreram à Corte Interamericana, mas aqueles que tinham mais informações já comprovadas do Estado ser responsável pela morte tiveram resposta positiva.

\section{CRISTINA BUARQUE DE HOLLANDA:}

Nilmário, mesmo sem poderes, essa Comissão presidida por você conseguiu acesso a documentos da Marinha que pela primeira vez significaram a admissão de participação na guerrilha [do Araguaia] por parte de uma das Forças Armadas. Foi um rompimento importante com o discurso negacionista que predominou até então a respeito desse tema. Você tem ideia se esse dado novo que vocês trouxeram a conhecimento público teve alguma relação com o acionamento da Comissão da OEA por familiares [de mortos e desaparecidos]?

\section{NILMÁRIO MIRANDA:}

Cristina, para a emergência dos direitos humanos no Brasil ganhar força, usamos muito a rede mundial. No meu primeiro mandato (1990-1994), nós tínhamos quase quinzenalmente um encontro numa embaixada, ou da Suécia, Itália, França, Espanha, Portugal, Holanda, Bélgica. Interessava [para eles] os direitos humanos no Brasil. Eles sempre tinham conselheiros de direitos humanos porque eles sabiam que $o$ avanço ou não avanço dos direitos humanos no país dependia muito do destino dos mortos e desaparecidos porque a tendência era abafar.

\section{CRISTINA BUARQUE DE HOLLANDA:}

Você se refere ao avanço dos direitos humanos em geral, às várias agendas contempladas nessa grande etiqueta?

\section{NILMÁRIO MIRANDA:}

Sim. Esse [era o] ponto que envolvia o desafio maior. Envolvia os militares e as Forças Armadas. [Era o] limite imposto pela anistia. Qualquer coisa em que mexíamos nos acusavam 
de revanchistas e de não aceitar a pacificação do país. Os estrangeiros percebiam isso, mas não podiam ingerir isso de uma maneira interna. Eu circulava muito entre esses países e a comissão de familiares também. Criamos vínculo com os chilenos, argentinos e depois com os paraguaios para que avançássemos juntos.

\section{CRISTINA BUARQUE DE HOLLANDA:}

Esses vínculos começam a se estabelecer a partir da Comissão Externa?

\section{NILMÁRIO MIRANDA:}

Sim. Também começou a aparecer gente do lado de lá [dos militares] que abria alguma coisa. Nos chegou a informação que tinha documentos. A história verdadeira foi essa: eu procurei Maurício Correia, que era Ministro da Justiça depois do impeachment de Collor naquele breve governo de Itamar Franco. Maurício era um cara bem avançado, tinha uma ótima noção de direitos humanos, foi presidente da OAB [Ordem dos Advogados do Brasil]. Eu Ihe disse que tínhamos sido informados sobre a revelação de documentos e queríamos fazer uma lei que reconheça os mortos e desaparecidos. Ele concordava com isso. A minha proposta era fazer uma lei como a do Chile, para toda vítima de violência política. Pegava gente que morreu e desapareceu, mas também quem foi para o exílio, que foi demitido ou exonerado, expulso das Forças Armadas, empresas e universidades.

\section{CRISTINA BUARQUE DE HOLLANDA:}

Era o que depois viria a unificar as pautas, no que veio depois a ser a Comissão de Anistia.

\section{NILMÁRIO MIRANDA:}

Exatamente. Ele gostou da ideia. Ele encarregou alguns assessores de fazer isso conosco e fez um pedido aos três últimos chefes militares do Ministério da Defesa de que tudo que houvesse da lista daqueles 136 desaparecidos políticos fosse enviado a ele, internamente, sem publicidade. Eles fizeram isso.

\section{CRISTINA BUARQUE DE HOLLANDA:}

Isso já significava um reconhecimento oficial do Estado.

\section{NILMÁRIO MIRANDA:}

O Exército foi cínico e hipócrita sobre a coisa. Mandou notícias de jornal sobre cada uma das vítimas. Em geral fake news, que era a versão oficial. 99,9\% eram falsas, para justificar a morte e o desaparecimento, tanto os mortos oficiais quanto os desaparecidos. E soubemos que, na Aeronáutica, em alguns casos, se admitiu versões distintas. Na Marinha foi uma bomba, aí nós fomos em cima do Maurício Correia e ele disse que não podia abrir porque havia assegurado que as informações seriam protegidas. Nós fizemos o golpe de jogar verde para colher maduro: fizemos o requerimento pedindo que ele fornecesse os documentos para a Comissão que tratava deste assunto. Ele deu os documentos dizendo que [fazia isso] desde que a confidencialidade fosse mantida. Nós fizemos uma reunião na Comissão, quebramos a confidencialidade e tornamos público. 
ENTREVISTA COM NILMÁRIO

MIRANDA

Cristina Buarque de Hollanda

\section{CRISTINA BUARQUE DE HOLLANDA:}

Como tornaram públicos? Com a imprensa?

\section{NILMÁRIO MIRANDA:}

Nós tínhamos muito apoio da imprensa. Dentro da Veja, no Jornal do Brasil, tínhamos ótimos parceiros, no Estadão, Globo e Folha [de São Paulo] também tinha bons parceiros. Nós criamos uma rede de amigos que cultivávamos. Caco Barcelos era um grande parceiro nosso. Na vala de Perus ele teve um papel fundamental. Quando descobríamos alguma coisa, procurávamos um ou outro parceiro. Eles tinham muito poder que nós para investigar. Nós não podíamos requisitar documentos nem requisitar pessoas. Já eles tinham seus meios de ir a fundo. $E$ também tínhamos a rede internacional. Nós lutávamos para que o Brasil assinasse todos os tratados e convenções que envolvesse os direitos humanos. A Constituição dizia que o que fosse da esfera internacional entraria como emenda constitucional, ou seja, penetraria a ordem jurídica. Ou seja, queríamos introduzir na ordem jurídica avanços que nós não conseguimos na Constituição nem na positivação dos direitos pós-Constituição. Era uma estratégia. Essas minhas viagens pelo mundo inteiro tinham a ver com isso também. Eu e vários de nós defendíamos o óbvio: direitos humanos não eram de esquerda! Não era o PT nem o PC do B. Direitos humanos de todos: direita, esquerda e centro. Eu tinha uma clareza de que a Comissão de Direitos Humanos só criou quando a direita apoiou. Me refiro à direita civilizada, hoje a nossa dificuldade é que direita em sua maioria aderiu à barbárie. Mas nós buscamos sempre a direita civilizada.

\section{CRISTINA BUARQUE DE HOLLANDA:}

Nilmário, no seu livro você faz muitas críticas à agenda de privatizações do PSDB [Partido da Social Democracia Brasileira], mas você ressalva que os direitos humanos eram um ponto de encontro com o PT. Tinha alguma diferença na maneira de entender os direitos humanos? Porque a agenda dos direitos humanos é extensíssima. Na maneira de priorizar um ou outro tópico?

\section{NILMÁRIO MIRANDA:}

Eles apoiaram o tópico mortos e desaparecidos. No dia 8 de maço de 96 foi eleito o presidente da Comissão de Direitos Humanos. Nós chamamos o [Nelson] Jobim, Ministro da Justiça.

Aquele Jobim que foi relator da Constituição. Ele sempre foi um freio forte para tudo, mas ao mesmo tempo tinha uma sensibilidade e sabia que era importante. E nós sempre chamávamos as organizações da sociedade para audiências públicas. Os conselheiros das embaixadas de diversos países sempre apareciam e eu agradecia a presença deles no meu discurso. Nós colocamos os pontos prioritários, que fazem avançar todos os direitos humanos no Brasil. Ponto 1: mortos e desaparecidos políticos. Fernando Henrique e Lula tinham assumido um compromisso com as famílias antes da eleição afirmando que se fossem eleitos tocariam esta pauta. Depois de eleito ele ficou quieto e nós fomos lembrar o Ministro da Justiça, o Jobim. As famílias foram em peso e o Ministro assumiu o compromisso. Nossos pontos subsequentes eram violência doméstica, a mulher, eram os pontos que ninguém avançava. Era tirar da justiça militar os crimes contra vida. 


\section{CRISTINA BUARQUE DE HOLLANDA:}

O chamado entulho autoritário...

\section{NILMÁRIO MIRANDA:}

Sim. Para mim, foi uma grande surpresa o artigo 68 das disposições transitórias. Os remanescentes quilombolas eram um assunto que eu praticamente desconhecia, mas puseram ali. Eu sempre achei que mulher e racismo são o limite da nossa democracia, patriarcalismo e toda a herança da casa grande com as mulheres, sobretudo as negras. $\mathrm{E}$ o racismo propriamente dito. Estes sempre foram entraves para a democracia. Nós pusemos todos estes pontos e também o reconhecimento da competência da Corte Interamericana, que suas decisões deveriam ser juridicamente aceitas aqui. Pleiteávamos uma aceitação tanto do sistema da OEA quanto do sistema ONU [Organização das Nações Unidas]. Também buscamos reforçar as agências que atuavam como a OIT [Organização Internacional do Trabalho] contra o trabalho infantil, trabalho escravo e degradante. Com a UNICEF [Fundo das Nações Unidas para a Infância] fizemos o mesmo também. Tudo isso para eliminar o nosso entulho. A ideia era levar ao limite os princípios defendidos nos tratados internacionais que o Brasil ratificava e aqueles previstos na Constituição. Era uma estratégia boa e fundamental.

\section{CRISTINA BUARQUE DE HOLLANDA:}

Como era a relação de vocês com os movimentos de familiares? O Tortura Nunca Mais foi um grupo que, em diferentes momentos, assumiu uma postura pública de recusa de diálogo com o Estado.

\section{NILMÁRIO MIRANDA:}

São posições respeitadas e bem fundamentadas. Antes de ser aprovada a lei, eu tinha sido presidente da Comissão Externa [de Mortos e Desaparecidos] e rodei o país e por isso conhecia muitas famílias, uma a uma. Como presidente eu procurei me unir com os grupos Tortura Nunca Mais. O de Minas nos apoiava. Não tinha sentido fazer uma comissão especial de mortos e desaparecidos sem as famílias. Como elas participariam se não tivesse uma maioria clara? Mesmo no Rio de Janeiro, AS FAMÍLIAS nos apoiaram. Houve uma dissidência no grupo do Rio que não nos apoiou. E o pessoal do Tortura Nunca Mais que não apoiou não era de familiares: Flora [Abreu] e Cecília [Coimbra], que eram pessoas fundamentais em todo o processo, mulheres muito corajosas, mas eram contrárias à ideia de fazermos a lei com o Fernando Henrique [Cardoso].

\section{CRISTINA BUARQUE DE HOLLANDA:}

O cerne da crítica delas era relativo ao escopo da lei, que deixava o ônus da prova [da violência da ditadura] às vítimas?

\section{NILMÁRIO MIRANDA:}

Não só por isso, porque também não podia punir os torturadores. Esse limite já estava dado. Eu lembro do Gilney Amorim [Viana], que é companheiro da Iara Xavier, apresentou emendas ao projeto de lei e todas foram consideradas inconstitucionais porque o entendimento é que violavam a Lei de Anistia pela leitura dos crimes conexos. Eram todas vetadas por isso. Todas. Mas ele não queria deixar passar sem marcar esta posição. Uma indenização do Estado é um 
reconhecimento objetivo do Estado e achávamos que era um avanço, assim como a anistia mesmo perdoando a tortura foi um avanço. Esse caráter ambíguo da Lei de Anistia. Nós conseguimos então abrir aqueles documentos.

\section{CRISTINA BUARQUE DE HOLLANDA:}

Imagino que você tenha tido uma atuação muito próxima ao Gilney nesse momento.

\section{NILMÁRIO MIRANDA:}

Claro. A Iara praticamente se mudou para Brasília. Ela era funcionária do estado do Mato Grosso e o Gilney veio eleito. Nós fomos companheiros antes e durante as nossas prisões em Linhares [em Minas Gerais]. Em 67 e 68 ele era da Corrente Revolucionária e eu era da POLOP [Organização Revolucionária Marxista Política Operária]. Tínhamos um laço histórico. Quando ele casou com a Iara, ela tinha perdido os dois irmãos [desaparecidos da ditadura].

CRISTINA BUARQUE DE HOLLANDA: E o marido.

\section{NILMÁRIO MIRANDA:}

Sim, o pai do Arnaldinho. A própria mãe dela tinha sido uma das companheiras do Marighella por um certo período e o pai viveu na clandestinidade a vida inteira dirigindo o PCB [Partido Comunista Brasileiro]. Era uma família totalmente destruída pela ditadura. Ela que me ganhou para entrar. Ela veio morar aqui porque o Gilney conseguiu se reintroduzir no Banco do Desenvolvimento [depois de cassado durante ditadura]. Pela amizade minha com o Gilney, minha mulher, a Stael [Miranda], se tornou grande amiga dela, nós passávamos férias juntos. Ela quem me aproximou do tema dos mortos e desaparecidos políticos, porque meu tema era 0 da reforma urbana.

\section{CRISTINA BUARQUE DE HOLLANDA:}

Isso antes de você se tornar deputado federal e chegar à Brasília.

\section{NILMÁRIO MIRANDA:}

Sim. Quando eu cheguei à Câmara, a minha prioridade lá era a reforma urbana. Tanto que eu fui relator do Estatuto da Cidade, da Lei Nacional de Saneamento, da Lei do Inquilinato.

\section{CRISTINA BUARQUE DE HOLLANDA:}

Mas você conta no livro que logo no início tentou desarquivar a CPI [dos Mortos e Desaparecidos].

\section{NILMÁRIO MIRANDA:}

Quando nós fundamos a Comissão de Direitos Humanos, ela era permanente.

\section{CRISTINA BUARQUE DE HOLLANDA:}

Nesse momento da Comissão de Direitos Humanos é que a sua prioridade era outra?

\section{NILMÁRIO MIRANDA:}

É. Eu já tinha atuado na Comissão Externa dos Mortos e Desaparecidos Políticos e já estava profundamente envolvido com o tema. Quando nós fundamos a Comissão de Direitos Humanos 
ENTREVISTA COM NILMÁRIO

MIRANDA

REVISTA ESTUDOS POLÍTICOS Vol. 10 | N.2 ISSN 2177-2851
Cristina Buarque de Hollanda

nós não podíamos ficar só neste item, tínhamos que atuar nos outros temas que apresentamos. Tinha uma coisa própria de mulheres, de saúde, de reforma agrária e eu peguei o foco da violência, que abarcava o social, os negros, as mulheres, racismo, quilombos, violência NO CAMPO, que era o epicentro, a violência como forma de lidar com os conflitos. Eu fui pegando outros temas dos direitos humanos. Quanto ao grupo Tortura Nunca Mais, ele nos apoiou integralmente em São Paulo, no Rio Grande do Sul, Paraná, Santa Catarina e Minas, com ressalvas porque lá tinha a Heloísa Greco, que era muito vinculada à mesma linha de trabalho da Cecília Coimbra e da Flora, no Rio. E este fato não era um problema para a gente. O grupo da Bahia também nos apoiou integralmente, com a Diva Santana, da guerrilha do Araguaia. Para eles, tudo que tirasse do Araguaia por debaixo do tapete e trouxesse para a cena pública era fundamental. O Araguaia estava jogado para debaixo do tapete. O grupo de Pernambuco também nos apoiaram, além das famílias do Rio: Vitória Grabois, coronel Zé Luís, o pessoal do PC do B, do grupo da guerrilha do Araguaia, que era muito forte no Rio. Todos estes grupos apoiaram a lei marcando posição contrária.

\section{CRISTINA BUARQUE DE HOLLANDA:}

E vocês vocalizaram o objetivo de alguns familiares de marcar oposição quando apresentavam emendas ao projeto do governo.

\section{NILMÁRIO MIRANDA:}

Sim. Gilney fazia isso em nome das famílias. E perdia tudo. Eu tentei com o José Aníbal, que era um amigo da Dilma que era da POLOP em Minas e foi exiliado, eu o conheci na luta. Ele era o líder do PSDB na Câmara. Eu sugeri que tentássemos a obrigatoriedade de entregar documentos e ele me disse: "Nilmário, sinto muito." O [Nelson] Jobim disse isso também. Ele me disse que talvez me contasse um dia o que os custou chegar até à lei do jeito que foi aprovada.

\section{CRISTINA BUARQUE DE HOLLANDA:}

Você acha que teve um empenho forte do Jobim para chegar a esse formato da lei?

\section{NILMÁRIO MIRANDA:}

Houve uma postura. Ele falou que não podia contar, mas que tinha sido duro. E o José Aníbal que tinha sido exilado e era amigo pessoal nosso também falou das dificuldades.

\section{CRISTINA BUARQUE DE HOLLANDA:}

E os familiares também tinham trânsito com ele?

\section{NILMÁRIO MIRANDA:}

Sim. Nós também tínhamos boa relação com o José Gregório [chefe de gabinete de Nelson Jobim na altura de criação da Comissão Especial de Mortos e Desaparecidos Políticos]. Ele era ótimo, mas ele era o maior ídolo do Fernando Henrique. Ele era amigo nosso, mas tinha uma lealdade enorme com o Fernando Henrique. Daí que nós criamos fortes vínculos com uma turma do PSDB. A turma dos grandes advogados de São Paulo - José Carlos Dias, do PSDB, foi meu advogado quando eu era preso político. O Belizário dos Santos Júnior, Luís Franciscano Filho, que era advogado da Folha, Almino Afonso, todo esse pessoal era gente MUITO amiga, 
ENTREVISTA COM NILMÁRIO

MIRANDA

REVISTA ESTUDOS POLÍTICOS Vol. 10 | N.2 ISSN 2177-2851
Cristina Buarque de Hollanda

muito ligada e ao mesmo tempo eram do PSDB. Então eles não iam comprometer a linha do governo do partido por causa desta pauta. Eles tendiam a apoiar, mas não estavam dispostos a bancar a pauta. Mas o pior dos mundos para nós é se ficássemos isolados na pauta, PT e PC do B. Não existia PSOL ainda.

\section{CRISTINA BUARQUE DE HOLLANDA:}

Então essa conversa com o PSDB foi fundamental para a pauta avançar?

\section{NILMÁRIO MIRANDA:}

Foi. E também buscar algum apoio do PMDB. Como foi com o Jobim, do Roberto Valadão.

\section{CRISTINA BUARQUE DE HOLLANDA:}

E como foi o acordo para que [o projeto do governo de criação da Comissão Especial de Mortos e Desaparecidos Políticos] fosse aprovado sem emendas?

\section{NILMÁRIO MIRANDA:}

Isso aí foi feito o José Aníbal. Ele falou: a lei é essa, chegamos a esse acordo e ponto final.

\section{CRISTINA BUARQUE DE HOLLANDA:}

Então isso precisou ser negociado com todos os parlamentares?

\section{NILMÁRIO MIRANDA:}

Todos. Um por um. Partidinho, partideco, partido de centro, partido de centro-direita.

\section{CRISTINA BUARQUE DE HOLLANDA:}

Eu imagino que seja uma coisa impressionante conseguir orquestrar um grupo tão grande de pessoas.

\section{NILMÁRIO MIRANDA:}

A tortura era e é muito aceita pela população. Ela pensa que quando um bandido que mata um trabalhador e destrói uma família sofre tortura seria justo. Essas pessoas justificam a tortura contra a figura do criminoso cruel. Em resposta a isso eu buscava relatos de pessoas inocentes que sob tortura assumiram culpa do que não fizeram e que foram condenadas e tiveram suas vidas e famílias destruías. Há vários casos desse no país. Um dos mais famosos é do Vagner [Vaguinho] de Congonhas. Ele ficou oito anos e três meses preso. Ele assumiu o crime que foi de autoria de outra pessoa. Ele entrou na justiça e ganhou, mas caiu nos precatórios e não recebeu um centavo. Vive numa pobreza. O caso do Roberto Lins dos Santos, de Varginha. Ele foi acusado de ter estuprado e assassinado a própria namorada com deficiência auditiva e depois foi comprovado que não foi ele. Tem um caso de um homem chamado Marco Aurélio era um garoto em Três Corações que, sob tortura, confessou o crime de um vigia de posto de gasolina da BR382. Tem o caso de um garçom que foi transmitido por todas as emissoras de televisão que ocorreu em Bom Jardim, Juiz de Fora. Ele confessou ter estuprado a filha e não houve um estupro, a criança tinha um tumor na vagina. Eu buscava casos exemplares de como a tortura deturpava a justiça também no campo, com indígenas, onde a tortura leva a pessoa a confessar coisas que ela não fez e ela é criminalizada por isso. O Pará e Paraná eram o 
ENTREVISTA COM NILMÁRIO

MIRANDA

REVISTA ESTUDOS POLÍTICOS Vol. 10 | N.2 ISSN 2177-2851
Cristina Buarque de Hollanda

epicentro da violência no campo. Nós também fazíamos um levantamento da atuação de grupos de extermínio. Mapeamos a Firma no Amazonas como um grupo de extermínio forte lá. Tinha grupos dominados pelo crime que atuavam dentro do estado do Acre e no Espírito Santo, controlavam o poder político: assembleia, Ministério Público estadual, polícia. Aquele famoso major Hildebrando da serra elétrica no Acre, um homem intocável. O Le Cocq no Espírito Santo, ele era um famoso inspetor no Rio, era um ídolo porque matava bandido. E criaram a escuderia Le Cocq, que era a legalização dos esquadrões da morte. Pegamos casos de esquadrões da morte perseguindo lideranças populares em São Paulo, que tinha tradição de tortura desde o delegado [Sérgio] Fleury. Tinham feito a chacina de Carandiru. O caso Maria da Penha foi um caso exemplar: uma professora universitária casada com um professor universitário oriundo do Peru e ele a deixou paraplégica. A partir da impunidade aqui nós nos mobilizamos para penalizar o caso na esfera internacional. Para não cumprir a sentença contra o Estado brasileiro, assumimos um compromisso, eu e a Ministra das Mulheres fizemos um acordo extra de fazer uma lei que criminalizasse a violência doméstica - a Lei Maria da Penha - e que abrisse cem delegacias de mulheres e dirigidas por mulheres. Usamos casos exemplares para podermos desenvolver leis e políticas públicas para enfrentar os problemas que esbarravam nos resquícios da cultura perversa de violência e de machismo.

\section{CRISTINA BUARQUE DE HOLLANDA:}

$E$, no caso dos desaparecidos, imagino que os casos emblemáticos também tenham sido uma maneira importante de atuação neste sentido.

\section{NILMÁRIO MIRANDA:}

Claro. Nós nunca separamos quem foi da luta armada de quem não foi. Nunca separamos porque nós achamos legítimo recorrer às armas em condições nas quais todos os caminhos se encontram fechados. Isso vem desde a doutrina das Igrejas, São Tomás de Aquino: à resistência ao franquismo, salazarismo, às ditaduras. Eu lutei muito pela criação do Tribunal Penal Internacional e os tipos penais que seriam contemplados por ele. Foi sempre muito difícil tipificar o terrorismo, porque muitas vezes o que se denominava por este nome era uma luta armada e legítima. $O$ país evadido pelos nazistas e fascistas, em luta anticolonial, contra o escravagismo. Nessas condições é legítimo usar de recursos que numa democracia são considerados terroristas. Não podemos aceitar terrorismo numa democracia, mas também não podemos admitir que este termo seja usado para criminalizar movimentos sociais. Nós sempre tivemos muito cuidado de não aceitar este jogo. Herzog nunca pegou numa arma na vida e foi tratado como se fosse um terrorista, foi morto de forma tão cruel como qualquer outro que foi para a luta armada.

\section{CRISTINA BUARQUE DE HOLLANDA:}

Nilmário, eu gostaria de mudar um pouco o tema da nossa conversa e falar sobre a Comissão de Anistia, de que você participou como conselheiro.

\section{NILMÁRIO MIRANDA:}

Houve um caso exemplar do qual fui relator - o do cabo Anselmo. Ele recorreu à anistia porque foi perseguido até 1971, num quadro que contempla os requisitos que a Comissão de Anistia preconiza. Foi expulso da Marinha, preso político, exilado e, portanto, ele desejava que a 
ENTREVISTA COM NILMÁRIO

MIRANDA

REVISTA ESTUDOS POLÍTICOS Vol. 10 | N.2 ISSN 2177-2851
Cristina Buarque de Hollanda

Comissão de Anistia fizesse a Marinha reintegrá-lo por tudo o que ele sofreu na ditadura militar. Em 71 ele mudou de lado e ofereceu agir como infiltrado pelo [delegado Sérgio] Fleury. Como eu deveria agir num caso desses? Eu não tenho formação jurídica, não sou advogado. Eu queria ouvir o máximo de opiniões de juristas e não especializados. Eu fiz um voto comparando o paradigma da Constituição de 67, que era o de esquecimento e impunidade, e o paradigma de 88, mesmo não podendo rever a Lei de Anistia, que era o da reparação e da verdade. Abria espaço para criação da Comissão da Verdade, para a reparação com a Comissão de Anistia e o Memorial da Anistia. Por isso entendi que o paradigma de 88 nos proibia de anistiar um torturador. Usei duas vertentes: primeiro, sobre uma dúvida razoável se ele não foi uma pessoa infiltrada a vida inteira, pois havia muitos depoimentos neste sentido, desde que ele surgiu, de que ele seria um provocador. Era muita gente que falava isso dele e eu recuperei esta história de bater duro no Anselmo, que era muito provocativo no jeito de atuar em 61 e 62, na véspera do golpe. E quando ele supostamente muda de lado ele passa a entregar a pessoas que serão mortas depois de torturas, inclusive [alguns constam] entre os desaparecidos, cujo caso mais extremo é o de sua companheira, a Soledad Barret, na chácara de São Bento, na qual a ditadura montou uma cena para simular uma chacina de cinco pessoas. Nós desmantelamos aquilo tudo. E com isso eu consegui aprovar por unanimidade a recusa de anistia para ele. Pelo nosso paradigma atual, não é possível dizer que antes era da resistência, mas pedir anistia depois de ter sido torturador. Tortura é um crime imprescritível - inciso 42, artigo V, da Convenção da Tortura que nós assinamos. 0 projeto sobre a prevenção e o enfrentamento à tortura é meu e do Nelson Peregrino, de 2001. Eu saí do parlamento em 2002 e depois a Maria do Rosário como Ministra do governo Dilma mandou um outro projeto instituindo o mecanismo que é o pacto internacional. Ela apensou o projeto dela ao meu, porque o meu tinha vários anos de tramitação - desde 2001 até 2009 . O dela era muito mais completo. O nosso não tinha o tratado. Quando eu voltei num mandato curto de 2013-2014 eu fui relator de um projeto que inicialmente tinha sido meu, que foi apensado por ele e agora retornava para mim. Treze anos depois eu pego outro fio da meada da tortura.

\section{CRISTINA BUARQUE DE HOLLANDA:}

Você participou da criação da Comissão de Anistia? Poderia falar a respeito? Me parece que as bases sociais dela foram muito diferentes daquelas de criação da Comissão de Mortos e Desaparecidos, certo?

\section{NILMÁRIO MIRANDA:}

Elas [as duas comissões] são contemporâneas.

\section{CRISTINA BUARQUE DE HOLLANDA:}

Sim, mas quem articula a criação da Comissão de Anistia não foi quem se envolveu com a Comissão de Mortos e Desaparecidos.

\section{NILMÁRIO MIRANDA:}

Porque [a Comissão de Anistia] tinha grupos organizados sobretudo de pessoas ligadas a agências estatais: pessoal do Banco do Brasil, pessoal da Petrobrás, da Companhia Siderúrgica Nacional e os militares. A ditadura para se estabelecer tirou mais de seis mil militares nacionalistas e democráticos que eram contra o golpe. Eles estavam lutando pelo reingresso, 
ENTREVISTA COM NILMÁRIO

MIRANDA

REVISTA ESTUDOS POLÍTICOS Vol. 10 | N.2 ISSN 2177-2851
Cristina Buarque de Hollanda

para recuperarem a história e para receberem indenização. Eles estavam em associações e eram muito ligados ao Luiz Eduardo Greenhalgh e ao deputado Artur Virgílio, do PSDB. Ele próprio tinha sido de esquerda e seu pai fora cassado por ser nacionalista na época da ditadura. O Virgílio ajudou muito. Ele era líder do PSDB na Câmara. Como eu também fui membro até 2002 da Comissão de Mortos e Desaparecidos, onde fiquei sete anos consecutivos representando a Câmara, eu já era representante de uma das frentes de luta e eu apoiei integralmente todas as ações, quando a Comissão de Anistia foi criada, em 2001.

\section{CRISTINA BUARQUE DE HOLLANDA:}

E o seu apoio foi de que tipo? Foi encaminhando o projeto de lei que instaurou a Comissão de Anistia?

\section{NILMÁRIO MIRANDA:}

Esta lei ampliou muito [em relação à lei de criação da Comissão de Mortos e Desaparecidos], porque pegou toda forma de perseguição política. A laboral, por exemplo, a Comissão Especial de Mortos e Desaparecidos nem tocava nesta questão. Teve milhares de pessoas que foram demitidas pós-64, dos bancos, das fábricas. Não conseguimos entrar na questão do campo, porque não envolvia vínculo laboral, mas na Comissão de Anistia podíamos, quando havia prova da participação do Estado, [atribuir indenizações]. Qual sempre foi o nosso limite? O Estado é o responsável. No caso de 2001, se a perseguição política perpetrada pelo Estado levasse ao rompimento do vínculo laboral, vale a anistia. O decreto 477 é o que proibia de estudar na universidade e tinha um vínculo com a lei este tipo de perseguição na universidade pública porque impedia que o jovem conseguisse trabalho no futuro ou o forçava a mudar de profissão ou buscar outra coisa. A anistia teve o aspecto odioso de anistiar o torturador, mas em contrapartida conseguiu ao menos trazer a recuperação da cidadania para milhares de pessoas. Em 95, a Comissão Especial [de Mortos e Desaparecidos] alcança os mortos e desaparecidos, que era o lugar mais dramático da ditadura: tortura e desaparecimento forçado de pessoas são tipos penais do Tribunal Penal Internacional, que é o ápice dos crimes contra a pessoa. Nós pegamos desaparecimento forçado sempre associado à tortura, depois pegamos a perseguição política, o Estado sendo usado para impedir a cidadania, retirando direitos civis, sociais, econômicos e culturais das pessoas, partindo de um sistema autoritário, por isso se chama justiça de transição.

\section{CRISTINA BUARQUE DE HOLLANDA:}

Nilmário, me corrija, por favor, se eu estiver errada: esse processo começa a ser chamado assim, como justiça de transição, com o Paulo Abrão na Comissão de Anistia, quando ele começa a traduzir títulos de justiça de transição, de direito à memória e à verdade.

\section{NILMÁRIO MIRANDA:}

Não tinha este nome exato, mas eu como eu já disse, para nós trazermos para o cenário dos direitos humanos nós nos apoiamos muito na justiça internacional. E, para apoiar o Tribunal Penal Internacional, nós nos apoiamos muito em Nuremberg, quando surge a ideia de genocídio, até então inexistente. A ideia de um crime contra uma pessoa em específico, mas contra a humanidade, porque envolve o extermínio de um povo em sua totalidade. Os julgamentos transnacionais que ultrapassavam a ordem jurídica nacional. Em Nuremberg esses 
ENTREVISTA COM NILMÁRIO

MIRANDA

REVISTA ESTUDOS POLÍTICOS Vol. 10 | N.2 ISSN 2177-2851
Cristina Buarque de Hollanda

fatores vão aparecer juntos: um tribunal internacional para julgar o crime contra tortura, genocídio, desaparecimento forçado. A justiça de transição surge num momento em que não bastava indenizar as pessoas, era preciso que esses crimes não voltassem a repetir-se. A Comissão de Anistia abriu muito leque e permitiu a justiça de transição, que é uma justiça pósautoritarismo, pós-fascismo, pós-franquismo, pós-salazarismo, pós-ditaduras militares, e espero que um dia também seja pós-colonialismo. Alguns países já namoram com isso, porque o colonialismo legalizava a violência: tortura, detenção arbitrária, cárcere ilegal além dos outros crimes políticos.

\section{CRISTINA BUARQUE DE HOLLANDA:}

Nilmário, depois de atuar expressivamente na Câmara pela pauta dos mortos e desaparecidos políticos você assumiu a Secretaria de Direitos Humanos no governo Lula, com status de Ministério. Imagino que você tivesse que lidar ali com uma enormidade de pautas, mas em relação especificamente aos mortos e desaparecidos você ainda teve alguma atuação?

\section{NILMÁRIO MIRANDA:}

Claro. A lei 9140, além de eliminar qualquer hipótese de justiça, ela dava às FAMÍLIAS a obrigação de provar, com os arquivos inacessíveis, o que era muito perverso. E nós tínhamos que lidar com isso. Imediatamente, quando eu cheguei [no Ministério], eu trabalhei nisso através de uma medida provisória para que abrangesse outros casos de violência política.

\section{CRISTINA BUARQUE DE HOLLANDA:}

Você atuou na expansão da lei?

\section{NILMÁRIO MIRANDA:}

Nos casos de suicídio forçado. Nós pegamos o caso da Iara Iavelberg, que foi um suicídio forçado. Tinha indícios de que ela se suicidou para não ser presa em Salvador. O caso da Maria Auxiliadora Lara Barcelos, que se atirou num trem em Colônia, na Alemanha, no exílio e nunca se libertou da tortura. Frei Tito também, que acordava e via o Sergio Fleury em todo o canto. 0 caso do Luís Antônio de Santa Bárbara, quando prenderam o Lamarca e o Zequinha. Nunca consegui provar que não foi suicídio, mas se foi suicídio, foi forçado pelas circunstâncias. 0 primeiro grande embate na Comissão de Mortos e Desaparecidos políticos foi o de Lamarca e Marighela e da chacina da Lapa, porque não aconteceram dentro do DOI-CODI, nem em instalações da Marinha, da Aeronáutica ou do Exército. Aí nós estendemos o conceito de dependência militar ou assemelhada; nós estendemos para cerco: o Estado tinha o controle da situação e do local, era o senhor da situação para buscar quem quer que fosse da luta armada ou não. Suicídio também é isso. Todas as mortes podiam derivar de uma ação objetiva do Estado.

\section{CRISTINA BUARQUE DE HOLLANDA:}

Imagino que tenha sido saudado pelos movimentos de familiares.

\section{NILMÁRIO MIRANDA:}

Inclusive a minha dificuldade eleitoral hoje tem a ver com isso. O Nilmário é defensor de terrorista, de bandido, de puta, de veado, de macumbeiro. Esse tipo de pensamento está na 
cabeça do povo. Às vezes até mesmo numa conversa de bar com um companheiro de partido eu ouvi algo como: "você não acha que tem um certo exagero esse negócio de defender os bandidos presos?!" E eu sempre respondi que as pessoas querem que o bandido sofra muito, para além do que a lei permite até entrar um parente. Eu dizia que "vai ter uma coisa qualquer e aí você vai querer que o seu parente tenha um tratamento digno. Se ele for branco, de classe média, você vai querer isso."

\section{CRISTINA BUARQUE DE HOLLANDA:}

Nilmário, agradeço muito por me receber. Foi um prazer conversar com você.

(Entrevista publicada em 2019)

\section{Cite esta entrevista}

MIRANDA, Nilmário, 2019. Entrevista com Nilmário Miranda, conduzida por Cristina Buarque de Hollanda. Revista Estudos Políticos: a publicação semestral do Laboratório de Estudos Hum(e)anos (UFF).Rio de Janeiro, Vol.10 |N.2, pp. 74-92, dezembro de 2019. 